\title{
Sobre representação e ética em Reigen de Arthur Schnitzler e suas releituras por Max Ophüls e Fernando Meirelles
}

\author{
[On representation and ethics in Reigen by $A$. Schnitzler and reinterpretations \\ by Max Ophüls and Fernando Meirelles]
}

\section{Valéria Sabrina Pereira ${ }^{1}$}

\begin{abstract}
In 1903 Arthur Schnitzler published the play Reigen (La ronde), which presented ten dialogues, each one occurring before and after a sexual conquest. The play intended to present typical behavior of social statuses through the way each figure behaved in achieving the same goal. The sexual inferences in the text caused a commotion and it was criticized as being immoral. In 1950 the play was transposed to the screen in a movie directed by Max Ophüls. This work was basically faithful to the play, but gave a certain lightness to the theme, which would seem to indicate a loosening of moral standards toward sex during that period. In 2012 Fernando Meirelles directed a film inspired by Schnitzler's play: 360. Even though the present day stands out for its sexual liberation, the movie does not show Ophüls' lightness. On the contrary, the film is bleak and depicts interpersonal relationships through the prism of guilt implied by infidelity and repressed sexual desires. In this article we will discuss how the theme of lust and sexual impulses expressed by Schnitzler evolved in its different representations after more than a century, and how the ethical problem was shaped to each work and its moment in history.
\end{abstract}

Keywords: drama; adaptations; cinema; sexuality; ethics

Resumo: Em 1903, Arthur Schnitzler publicou a peça Reigen (port. A ronda), a qual apresentava dez diálogos, cada qual se desenvolvendo antes e depois de uma conquista sexual. A obra pretende apresentar comportamentos típicos de diferentes classes sociais através da forma como se comportavam para chegar ao mesmo objetivo. A ciranda sexual apresentada no texto causou comoção em sua época e foi criticada por sua alegada imoralidade. Em 1950, a peça foi transposta para o cinema em um filme de Max Ophüls. Sua obra buscou ser fiel ao original, mas também concedeu uma certa leveza ao tema, o que parece indicar um alargamento nos padrões morais diante o sexo. Em 2012, Fernando Meirelles filmou uma releitura da peça de Schnitzler: 360 . Na atualidade, uma era marcada pela liberação sexual, o filme não mantém a leveza dada por Ophüls, mas, pelo contrário, é pesado e trata de relações interpessoais através do prisma do sentimento de culpa provocado por traições ou desejos sexuais reprimidos. Neste artigo, será discutido como a temática do desejo e dos impulsos sexuais trazida por Schnitzler se transformou com a passagem de mais de um século, e como a questão da ética foi modelada a cada obra e seu tempo.

Palavras-chave: drama; adaptações; cinema; sexualidade; ética

\footnotetext{
${ }^{1}$ Doutora em literatura alemã. Atualmente, desenvolve projeto de pós-doutorado na Universidade Federal de Minas Gerais. E-mail: valeriasabrinap@gmail.com

Pandaemonium, São Paulo, v. 16, n. 22, Dez/2013, p. 138-155
} 


\section{Categorias para a análise da ética na representação}

$\mathrm{Na}$ atualidade, alguns pesquisadores da ficcionalidade entendem que a apresentação feita de determinados valores morais em narrativas serve para formar a ética do receptor. $^{2}$ As mensagens transmitidas por estas seriam capazes de enriquecer o caráter, confirmar ou abalar seus valores. David H. RICHTER (2007), em seu artigo sobre a questão da ética em filmes, chega a definir filmes como "bons" ou "ruins" de acordo com o posicionamento ético que eles apresentam. Segundo essa classificação, Richter qualifica um filme como Irreversível de Gaspard Noë como ruim, apesar de qualquer excelência na técnica de filmagem, atuação e narração. Seu julgamento leva em consideração apenas a exibição explícita e excessiva de violência que ocorre no filme, sem que qualquer questionamento sobre o ato seja apresentado. Não creio que uma obra de arte, seja ela plástica ou narrativa, possa ser julgada simplesmente a partir da questão da ética, mas a abordagem de Richter é útil para sistematizar a interpretação da ética em representações e analisar como essa questão se apresenta em diferentes obras de arte.

Baseado em um estudo desenvolvido por Wayne Booth, RICHTER (2007: 141) desenvolve as seguintes categorias analíticas da ética na representação narrativa e fílmica:

- Ética de propósito retórico: Se aplica à causa final ou ao efeito produzido pela narrativa.

- Ética do narrado: Se aplica ao que é representado na trama, seus agentes, ações, escolhas e pensamentos.

- Ética do narrar: Se aplica tanto às técnicas narrativas, quanto às consequências éticas de como uma história é transmitida. Trata especialmente de estratégias narrativas que podem fazer com que se simpatize, ou não, com determinadas personagens, ideias ou escolhas.

- Ética da representação fílmica: Se aplica à questão da representação através da imagem. As mensagens transmitidas pela imagem, independente do uso da palavra.

\footnotetext{
${ }^{2}$ Aqui a moral deve ser entendida como as regras de conduta aplicadas em uma determinada época e sociedade, enquanto que a ética são os preceitos que se formam através da apresentação dessa moral na obra de arte, que entra em diálogo com a atuação das pessoas e a forma como a obra de arte configura esse conflito.
} 
Pereira, V. - Sobre representação e ética em Reigen

De acordo com essas categorias, será discutido, neste artigo, o desenvolvimento da questão ética em Reigen (1903) de Arthur Schnitzler e em suas releituras no filme Le ronde (1950) de Max Ophüls, e no filme 360 (2012) de Fernando Meirelles. Também será levado em consideração como esse desenvolvimento revela algo sobre a relação de suas respectivas épocas ${ }^{3}$ com a questão do impulso sexual.

\section{Reigen de Arthur Schnitzler}

No inverno de 1896-97, Arthur Schnitzler escreveu a peça de teatro intitulada Reigen (Ciranda), que foi traduzida para o português com o título de $A$ ronda. ${ }^{4}$ A peça pretendeu retratar parte dos hábitos culturais e sociais de sua época, como é observado em uma afirmação feita pelo próprio autor em carta enviada à amiga Olga Waissnix:

Durante todo o inverno, eu não escrevi mais do que uma série de cenas que são absolutamente impublicáveis, também não têm grande significância literária, mas que, se fossem desenterradas após algumas centenas de anos, elucidariam de forma peculiar uma parte da nossa cultura. ${ }^{5}$ (apud SPRENGEL 2007: 101, todas as traduções são da autora)

Reigen se constitui de uma sequência de dez diálogos; cada qual se desenvolve antes e depois do ato sexual, que se dá frequentemente entre pessoas que pouco se conhecem. $\mathrm{O}$ coito parece ser o objetivo das cenas. Apesar disso, ele é representado apenas através de uma breve pausa no diálogo que quase sempre se conclui com a despedida. Cada uma das personagens é apresentada por sua função social - prostituta, soldado, marido e mulher burgueses, conde etc. - e cada uma age de acordo com esse papel. O título da peça se deve ao fato de a sequência de personagens formar uma corrente, na qual o amante da primeira tem, no próximo diálogo, uma relação com uma segunda mulher,

\footnotetext{
${ }^{3}$ As variações na questão do tratamento ético e moral dado à sexualidade em Reigen e em suas adaptações também se devem à cultura dos diferentes países onde as obras foram produzidas - Áustria, França e o filme de roteirista britânico e diretor brasileiro - entretanto, essa questão não será abordada neste artigo.

${ }^{4} \mathrm{O}$ sucesso do filme La ronde (Ciranda) de Max Ophüls foi determinante para a tradução do título do livro em outras línguas, enquanto, em inglês, se manteve a referência francesa e o drama foi traduzido por La ronde. Em português, a peça de Schnitzler, assim como o filme de Ophüls, foram traduzidos por um falso cognato do francês: A ronda. Para evitar equívocos, os nomes originais serão mantidos neste artigo.

5 "Geschrieben hab ich den ganzen Winter über nichts als eine Scenenreihe, die vollkommen undruckbar ist, literarisch auch nicht viel heißt, aber, nach ein paar hundert Jahren ausgegraben, einen Theil unsrer Cultur eigentümlich beleuchten würde."
}

Pandaemonium, São Paulo, v. 16, n. 22, Dez/2013, p. 138-155 
Pereira, V. - Sobre representação e ética em Reigen

que terá relações com outro homem no próximo quadro, e assim sucessivamente até retornar à primeira personagem, fechando um círculo. Reigen apresenta uma forma vigorosa e inovadora em sua época: ela não é dividida em três atos segundo o padrão clássico, mas em dez diálogos que foram entendidos por muitos como um único ato. Dessa forma, a peça constitui uma contribuição original à fase de experimentação no teatro do final do século XIX.

O primeiro diálogo se dá entre uma prostituta e um soldado. A moça o seduz com a promessa de uma relação "gratuita" e, devido à pressa do soldado de retornar à caserna, eles se relacionam na rua. O rapaz é rude e sequer lhe diz o próprio nome, fazendo troça da prostituta quando ela anuncia o seu, Leocadia: “Ah... Também nunca ouvi um nome desses." (SCHNITZLER 1978: 71). A fala do soldado é truncada e ele se comunica em dialeto, como se observa no segundo diálogo, quando afirma para a camareira que ela não necessita ter medo do escuro, porque está em sua companhia: "Graças a Deus, nós somos nós!"7 (ibd.: 72). O uso do dialeto, compartilhado por outras figuras de classe baixa, como a própria camareira, aponta para uma formação pouco elevada. Além da fala, Schnitzler designa as classes e papéis sociais pela maneira como se portam em relação às preliminares do ato sexual. De forma geral, as mulheres se apresentam como reticentes, questionam fatores como o local que é escuro, o fato de estar ficando tarde ou a honra diante da família. Nada mais do que proforma, uma vez que a resistência ao ato sexual não é real. Na representação das mulheres também não é incomum que haja um certo jogo de interesses, quando elas provêm de uma classe social mais baixa do que o homem em questão, como a camareira que se deita com o filho de seus patrões, ou a bela jovem [süßes Mädel] que sai com um homem abastado que lhe paga um farto jantar. Mas sequer essa representação de gêneros é fixa, variando muito de acordo com o papel exercido por cada mulher. A exceção mais clara é a atriz, a mulher mais determinada da peça, que impõe regras ao escritor e faz graça ao pedir que ele descubra qual é o homem que ela está traindo ao se deitar com ele.

Muito embora boa parte das cenas apresente o encontro de casais que pouco se conhecem, é recorrente que um dos interlocutores questione o bem querer de seu parceiro, muitas vezes como uma espécie de justificativa para o ato sexual. As respostas afirmativas, contudo, não costumam ser mantidas após a relação. Uma vez que o desejo

\footnotetext{
6 "Ha... So an Namen hab ich auch noch nie gehört."

7 "Gott sei Dank, mir sein mir!"

Pandaemonium, São Paulo, v. 16, n. 22, Dez/2013, p. 138-155
} 
Pereira, V. - Sobre representação e ética em Reigen

sexual está satisfeito, o diálogo muda de tom, pois não há mais a necessidade dos embustes da sedução. Os diálogos costumam terminar em decepção. Tome-se por exemplo o soldado que sequer ajuda a camareira a se levantar do chão após o ato e logo corre para dançar com outras moças, ou a atriz que declara ao conde que não existe tal coisa como o amor.

O diálogo central apresenta o que seria considerado um relacionamento exemplar da classe burguesa. Já no leito, preparando-se para o sono, a esposa se espanta com o interesse do marido, o qual não tem o costume habitual de procurá-la para fazer amor - o que ele justifica afirmando que é importante que o marido não procure a mulher com muita frequência para garantir a "santidade" do casamento. O marido defende que, caso tivessem aproveitado ao máximo a paixão que sentiam um pelo outro, já não se amariam mais. Ele faz uma clara diferenciação entre a sua esposa que é "pura" e entrou no casamento sem ter conhecimento das coisas do amor, enquanto ele foi obrigado a um contato que julga devastador com essas "criaturas" (mulheres de "má conduta") para satisfazer os desejos antes de adentrar os laços do matrimônio. Mas, enquanto o marido se faz de moralista discursando contra essas "criaturas", sua mulher se demonstra fascinada pelo assunto e o inquire sobre esse mundo que deveria lhe ser desconhecido. Ela questiona se ele já se relacionou com mulheres casadas, e ele responde que sim, mas a amante haveria morrido cedo. Em seguida, o marido afirma ter a sensação de que todas as adúlteras morrem cedo. Esse diálogo apresenta o que se pretende de um casamento burguês: enquanto o homem tem suas aventuras antes do matrimônio, a mulher deve se manter praticamente imaculada, não tendo uma vida sexual regular sequer com o próprio marido para que ela continue "pura", diferente das "criaturas" com as quais ele se relaciona sexualmente. Uma vez que esse mundo da realização sexual é negado à mulher mesmo após o casamento, ela desenvolve um fascínio pela história de tais mulheres da vida, em um processo que relembra a história narrada em Madame Bovary.

Schnitzler procurou produzir um retrato daquilo que ele observava em sua época, na sociedade de Viena. Uma possível razão pela qual a obra causa desagrado é a ética do narrar, pois, apesar de apresentar pessoas que agem de forma considerada promíscua para a época, elas são definidas por traços leves e a promiscuidade ou infidelidade não são castigadas com resultados negativos - sequer é possível ter pena daqueles que são traídos, porque todos são peças responsáveis por fazer rodar esse 
Pereira, V. - Sobre representação e ética em Reigen

engenho de traições. Por outro lado, a discrepância entre a moral expressa nos diálogos e a atuação das personagens cria uma tensão evidente para o público, a qual constitui a ética do narrado e do propósito retórico. A constante contradição das personagens que, em seus discursos, garantem fidelidade, paixão e pureza, ao mesmo tempo em que se entregam facilmente para estranhos e abandonam qualquer interesse minutos depois, é capaz de provocar desagrado no público até os dias de hoje. O escândalo que Schnitzler causou em sua época se devia principalmente à representação de todas as camadas sociais envolvidas em atos sexuais que eram, inclusive, imorais.

Os críticos mais perspicazes entenderam que o propósito dessa "comédia do amor" era explicitar a hipocrisia dessa sociedade e condenar esse moralismo duplo, onde o purismo é defendido por palavras, mas nunca praticado. Ou, alternativamente, adequar o discurso e a ética às necessidades sexuais. A história da recepção da peça demonstra que a sociedade da época não estava preparada para compreendê-la como sátira, em outras palavras, para reconhecer que eles próprios, ou pessoas que lhes eram próximas, se portavam de tal maneira. O livro foi publicado em 1903 e teve sua história marcada por protestos. Após a encenação da peça ter sido proibida tanto em Munique quanto em Budapeste, antes mesmo da estreia, Schnitzler passou a recusar a permissão para quem quer que desejasse encenar a obra. Apenas após o final da monarquia, o autor considerou que a sociedade já seria liberal o suficiente para que a peça pudesse ser encenada, o que ocorreu em dezembro de 1920 em Berlim e em janeiro de 1921 em Viena, mas não sem problemas. A peça foi acusada de ser vergonhosa e indecente, mas mais do que isso, ela foi classificada como "uma sujeira judaica nojenta"8 (apud FLIEDL 1996: 34), denunciando que parte da reação negativa à peça se devia mais ao crescente antissemitismo na Europa e ao fato de Schnitzler ser judeu, do que ao conteúdo da peça propriamente dito. Muitos dos que testemunharam contra a peça nunca haviam assistido ou lido a obra, mas afirmavam conhecer o seu conteúdo de “ouvir dizer". O processo que julgava a possibilidade de censurar a peça em Viena, contudo, teve um resultado positivo para Schnitzler, como pode ser verificado na seguinte citação do parecer do vice-presidente do tribunal, Tils:

Schnitzler ocupa uma posição proeminente no movimento literário moderno. Ele sabe captar os mais íntimos mecanismos da vida com realismo acurado, e iluminar a vida da alma humana como um experimentado analista. Através de seus diálogos espirituosos,

\footnotetext{
8 "ekelhafter Judenschmutz"

Pandaemonium, São Paulo, v. 16, n. 22, Dez/2013, p. 138-155
} 
Pereira, V. - Sobre representação e ética em Reigen

sua linguagem inovadora e seus flashes de ideia luminosos, ele prende o interesse mesmo onde o objeto causa repulsa e, através da penetração artística da forma, ele se tornou um representante de uma vertente literária de caráter especial, apesar de alguma oposição. Sua obra da juventude, Reigen, também não nega essas características. ${ }^{9}$ (apud KOEBNER 1997: 50)

Além de ser um texto elogioso ao autor, é notável que as situações retratadas em Reigen sejam entendidas como uma representação realista da sociedade. O repulsivo é explicitado como em um experimento e, por que não dizer, um processo analítico, onde a mácula da sociedade deve ser tratada através da exposição ao problema que tanto se procura ocultar. Observe-se que o ato de processar livros devido a seu conteúdo que é entendido como uma ameaça à moral e à ética não era uma novidade, mas já havia ocorrido outras vezes, como no famoso caso de Madame Bovary. Assim como Schnitzler, Flaubert foi absolvido, mas é de interesse para este trabalho levar em consideração algumas palavras do advogado de acusação do processo contra o autor francês, Ernest Pinard:

Quem pode condenar essa mulher no livro? Ninguém. Esta é a conclusão. Não há no livro nenhum personagem que possa condená-la. Se encontrardes nele um personagem sensato, se encontrardes um único princípio em virtude do qual o adultério seja estigmatizado, eu estarei errado. No entanto, se em todo o livro não houver nenhum personagem que possa fazer-lhe abaixar a cabeça, se não houver uma única ideia, uma linha em virtude da qual o adultério seja aviltado, sou eu que tenho razão, o livro é imoral! (apud MORETTI 2009: 212)

O final trágico de Emma Bovary e a repulsa que sua história causou nos leitores não foram suficientes para entender o romance como uma obra que não apresenta sua personagem como modelo a ser seguido. Através do discurso do advogado fica evidente que ele apenas considera relevante a questão da ética do narrado. Efeitos da ética de narrar e do propósito retórico não são levados em consideração. A ética só estaria presente se estivesse claramente presente no narrado, sem a necessidade de qualquer tipo de interpretação para que o fundo ético seja explicitado. Reigen parece, assim, causar mal-estar por razões semelhantes.

\footnotetext{
9 "Schnitzler nimmt in der modernen literarischen Bewegung eine hervorragende Stellung ein. Mit scharfer Realistik weiß er die intimsten Lebensvorgänge zu erfassen und als erfahrener Analytiker das menschliche Seelenleben zu beleuchten. Durch seinen geistvollen Dialog, seine vornehme Sprache und durch leuchtende Gedankenblitze fesselt er das Interesse auch dann noch, wo der Gegenstand abstößt, und durch die künstlerische Durchdringung der Form ist er trotz mancher Gegnerschaft zum Vertreter einer literarischen Richtung von besonderer Eigenart geworden. Auch sein Jugendwerk 'Reigen' verleugnet diese Eigenschaften nicht."
} 
Pereira, V. - Sobre representação e ética em Reigen

Infelizmente, os ataques contra Reigen não cessaram com o veredito favorável a Schnitzler e seu texto foi, por fim, censurado pelo nazismo e queimado junto a tantos outros na Queima de Livros que ocorreu em 1933 em Berlim.

\section{La ronde de Max Ophüls e Jacques Natanson}

A obra recobrou sua importância após o final da guerra quando, em 1950, foi filmada sob a direção de Max Ophüls, judeu alemão, exilado primeiramente na França e depois nos EUA, com o roteiro adaptado por Jacques Natanson. Em La ronde, há uma busca clara de produzir uma versão tão fiel quanto possível do texto de Schnitzler, mas deve se levar em consideração que, meio século depois e utilizando uma mídia diferente da original, uma série de modificações seriam inevitáveis. Como é observado por André Bazin (apud BOHNENKAMP 2005: 23) que compara adaptações de obras de uma mídia para outra, com traduções: "Uma boa adaptação deve poder reconstituir o original em sua substância segundo palavra e espírito. Mas nós sabemos que uma boa tradução exige um conhecimento íntimo da língua e de seu próprio espírito."10. A principal alteração feita foi a introdução de um narrador que apresenta a história e costura seus quadros. Suas primeiras palavras são:

Eu sou a personificação do seu desejo de saber tudo. As pessoas só conhecem uma única faceta da realidade. E por quê? Porque elas só veem um lado das coisas. Mas eu vejo todos os lados, porque eu tenho uma visão global das coisas. Isso me permite estar em todos os lugares ao mesmo tempo. Mas onde estamos? Em um palco? Em um estúdio? Já não se sabe mais. Estamos em uma rua. Estamos em Viena. Em 1900. [...] Estamos no passado. (OPHÜLS 1950)

Àqueles que não são familiares ao texto original, o narrador traz algumas importantes informações: a ação se passa em uma época distante, em 1900, e outra região, em Viena (o filme é francês). Além disso, o narrador também explicita a ambiguidade que se dará entre o formato teatral e cinematográfico: o tipo de ação que se desenvolve na tela é facilmente reconhecível como proveniente do teatro, mas as ferramentas que o cinema oferece não deixam de ser utilizadas, como a mobilidade das personagens principais

\footnotetext{
10 "Eine gute Adaptation [muß] das Original in seiner Substanz nach Wort und Geist wiederherstellen können. Wir wissen aber, daß eine gute Übersetzung eine sehr vertraute Kenntnis der Sprache und des ihr eigenen Geistes erfordert."

Pandaemonium, São Paulo, v. 16, n. 22, Dez/2013, p. 138-155
} 
Pereira, V. - Sobre representação e ética em Reigen

passando de um ambiente para outro e a introdução de algumas personagens secundárias aos diálogos. Entretanto, a presença do narrador não se deve tanto à mídia para a qual a peça foi transferida, mas, antes disso, a uma releitura da obra que a aproxima mais da modernidade no teatro. A figura do narrador conversa com o público, interage com as personagens e chega a interferir nas histórias (sempre tendo em vista a continuidade dos enlaces amorosos). Esse narrador não é um elemento cinematográfico, mas sim um elemento do teatro épico que causa o efeito de estranhamento na peça, lembrando sempre novamente ao público que se trata de uma obra ficcional, e não da vida real. Esse efeito é obtido já na fala inicial, quando ao questionar se ele está em um teatro ou estúdio, o narrador passeia por um palco e depois aparece junto a uma câmera, desfazendo a ilusão do cinema e lembrando que também ele é uma personagem dentro de um estúdio. A grandiosidade da obra de Ophüls está no fato de ser capaz de transformar a peça em filme sem descaracterizá-la como obra teatral, ao mesmo tempo em que não deixa de fazer uso das ferramentas da mídia cinematográfica e obtém um resultado que é moderno também em sua época.

No que diz respeito ao conteúdo dos diálogos (ou quadros), os dez encontros são mantidos e os diálogos são muito semelhantes aos escritos por Schnitzler, mas o lado de sátira social da peça se perde. Não há uma qualidade diferenciada na linguagem das personagens. Todas, desde o estrato social mais baixo ao mais alto, se comunicam de forma clara e fluente. Com raras exceções, elas também não são mais apresentadas de acordo com sua classe. A prostituta é introduzida pelo narrador como "moça", e a camareira só é reconhecida como tal quando ela atua em seu local de trabalho, antes disso, o narrador a apresenta utilizando seu nome próprio: Marie. Cada uma das personagens mantém uma certa individualidade a despeito dos papéis que devem representar na sociedade, fazendo com que o caráter do envolvimento amoroso se destaque. Além disso, há a representação do desapontamento de algumas personagens quando elas não encontram aquele que costumava ser seu amante, mas que agora está fazendo o jogo da sedução com uma nova pessoa, como é o caso do marido que espera pela amante em um restaurante, enquanto ela se entretém com um poeta.

Quando se compara a obra de Schnitzler com a de Ophüls, constata-se que o conflito entre o discurso e as ações da peça original é mantido, apresentando assim a mesma ética no aspecto narrado. A grande diferença entre a peça e o filme está na ética do narrar e na ética do propósito retórico. Quanto à ética do narrar, no filme se perdem 


\section{Pereira, V. - Sobre representação e ética em Reigen}

os gestos e atos que configuram a caricatura dos papéis sociais. Os gestos se tornam meros exageros da comédia que causam o riso mais do que repulsa à atuação das personagens. No que diz respeito à ética da representação fílmica, todos os atores são simpáticos e atraentes, seus atos, mesmo que moralmente condenáveis, têm graça e leveza. A figura do narrador marca o caráter da ética do propósito retórico, ou melhor dizendo, a ausência de crítica à promiscuidade. A constante troca de parceiros é celebrada pelo narrador que afirma que o carrossel do amor não deve parar. Os encontros e desencontros no constante movimento da busca amorosa devem ser apreciados por um olhar voyeurístico dos espectadores que desejam "saber de tudo" e que, agora, têm essa possibilidade oferecida pelo narrador. A função do filme é entreter com a representação da troca de parceiros que é realidade da vida afetiva e que, aqui, não deve ser condenada. No filme, a única traição verdadeira é a do casal central, unidos pelo matrimônio, pois os outros relacionamentos são furtivos, como volta e meia fica claro através de cenas que enfatizam o abandono do parceiro anterior, desconstruindo assim, mais uma vez, a crítica feita pelo texto original. Além disso, o filme representa a trama em uma Viena, fin de siècle, um ambiente que, após duas guerras mundiais, parece quase idílico. Este fato parece ter contribuído para reduzir a crítica que o público poderia fazer sobre a imoralidade das cenas apresentadas.

\section{0 de Fernando Meirelles e Peter Morgan}

O filme de Max Ophüls foi a adaptação mais famosa da obra que, em 2012, serviu como inspiração para o roteiro de Peter Morgan, 360. Como homenagem ao $150^{\circ}$ aniversário de Arthur Schnitzler, Morgan produziu o filme que foi anunciado como uma releitura de La ronde. 360 não mantém muito da história original (da peça ou do filme de Ophüls, que por vezes também foi citado por Morgan). Na "Coletiva de imprensa - filme 360" (2012), o diretor do filme, Fernando Meirelles, reduz essa inspiração ao fato de a história começar com uma prostituta em Viena e o ciclo ser fechado com esta mesma personagem. Mas é inegável que uma das principais inspirações é, na verdade, o formato da narrativa, que é episódica e tem como único fio condutor o fato de as personagens de cada cena estarem relacionadas com personagens apresentadas em outras cenas do filme. Essas relações, todavia, não são necessariamente contínuas como 
Pereira, V. - Sobre representação e ética em Reigen

em La ronde. Há passagens de uma cena para outra nas quais as personagens não têm qualquer vínculo e ocorre uma certa demora no desvendar onde se encontra o fio que as une. Como Meirelles afirma em entrevista para Matthew TURNER (2012), a estrutura de 360 não é circular como em La ronde, ela tem mais uma forma "cubista". Isso, evidentemente, não impede que a imagem do círculo, como menção à estrutura da narrativa, esteja presente em diferentes elementos do filme, como no título, onde 360 é uma referência a uma volta completa de 360 graus, ou no passeio que duas personagens fazem de carro na Ringstrasse, principal avenida de Viena que circunda o centro histórico. O passeio é concluído com a moça afirmando "Agora o círculo está completo", uma afirmação que serve tanto para o passeio da dupla quanto o círculo da narrativa, pois essa cena coincide com o retorno da prostituta da primeira cena. Ao ser perguntando por Ulrich LöSSL (2012) se a obra de cem anos de Schnitzler ainda serve como inspiração, Peter Morgan responde afirmativamente, e se refere principalmente à atualidade da estrutura narrativa:

O motivo de Schnitzler - a vida sempre gira continuamente e tudo está ligado um com o outro - foi muito importante para mim. Quando eu comecei a escrever, nós tivemos essa grande catástrofe bancária, a histeria da gripe suína e outras crises ao redor do mundo. Era uma loucura: Alguém espirrava no México e, em Nova York ou Sydney, todos usavam máscaras. Além disso, ocorreu que Steven Soderbergh filmou Contágio, sobre uma epidemia de um vírus. Para mim, 360 também é um filme sobre um vírus. Mas, em vez de bactérias, ele trata da responsabilidade de pessoas umas pelas outras. E do quanto estamos próximos uns dos outros. E também é um filme sobre o amor. ${ }^{11}$ (ibd.: s/p)

Aqui pode se observar que a relação entre Reigen e 360 vai além da estrutura, e toca também a questão do amor. Além disso, a atualidade da estrutura de Reigen se deve, em grande parte, ao processo de globalização vivido na atualidade, razão pela qual o filme 360 não se restringe à Viena, mas passa por diferentes cidades - Viena, Paris, Londres e três diferentes localizações nos EUA - e apresenta uma gama ainda maior de nacionalidades, contando com a participação de personagens brasileiras, russas, eslovacas e um argelino. A temática da globalização também é percebida através dos cenários onde as histórias se desenvolvem: no avião, no ônibus, em carros, aeroportos e

\footnotetext{
11 "Schnitzlers Reigen-Motiv - das Leben dreht sich immer weiter und alles ist miteinander verbunden war für mich sehr wichtig. Als ich mit dem Schreiben anfing, hatten wir die große Banken-Katastrophe, die Schweinegrippe-Hysterie und andere Krisen weltweit. Es war verrückt: Da nieste jemand in Mexiko, und in New York oder Sydney trugen alle Mundschutz-Masken. Hinzu kam, dass Steven Soderbergh Contagion über eine Virus-Epidemie drehte. Für mich ist 360 auch ein Film über einen Virus. Aber statt mit Bakterien hat er mit der Verantwortung von Menschen füreinander zu tun. Und wie nah wir einander sind. Und es ist auch ein Film über die Liebe."
}

Pandaemonium, São Paulo, v. 16, n. 22, Dez/2013, p. 138-155 
Pereira, V. - Sobre representação e ética em Reigen

hotéis, sem contar com o uso da internet e de telefones celulares. Mas o que chama a atenção nas palavras do roteirista é que, apesar de ter escrito uma história sobre relações humanas, ele se refere à possibilidade de contágio em grande escala. Isso parece ser um ponto principal de inspiração e remete inevitavelmente ao fato de que Reigen, apesar de não fazer nenhuma menção a doenças venéreas, frequentemente foi relacionada ao tema: já em 1913, Theodor REIK (apud KOEBNER 1997: 87) se queixava de que a obra não fazia nenhuma referência ao risco de contaminação. $\mathrm{Na}$ atualidade, em um livro sobre sífilis na literatura, Anja SCHONLAU (2005: 101) menciona Reigen apenas para constatar que não há sequer preocupação das personagens com o assunto. Contudo, isso não impediu que a peça fosse entendida como um bom modelo para se explicar a contaminação - assunto especialmente atual devido à preocupação com o vírus do HIV - ou até mesmo que fosse entendida como uma obra sobre o assunto, fato que se observa em uma das declarações de Fernando Meirelles para TURNER (2012): “[...] there's not much of La Ronde in 360. La Ronde is nine scenes of people having sex and spreading a disease, but there's this idea of one character meets the other, who meets the other, and one takes you to the next one." Os equívocos presentes na fala de Meirelles provavelmente não se devem a uma pobre interpretação do texto original, mas devido ao diretor não ter tido contato direto com a obra, baseando sua fala apenas em comentários de terceiros. Isso, por si só, é suficiente para demonstrar que, em uma época na qual o discurso sobre a transmissão de doenças venéreas é tão presente, Reigen e La ronde tendencialmente se relacionam com essa temática.

Quando procuram explicar qual é a temática de 360, roteirista e diretor oferecem pontos de vista complementares. Peter Morgan diferencia sua temática da apresentada em Reigen / La ronde afirmando que "em Schnitzler, trata-se, em primeiro lugar, de sexo, prazer e desejo. Em 360, trata-se, pelo contrário, acima de tudo da humanidade. E do desastre de ser humano." ${ }^{\prime 2}$ (LöSSL 2012: s/p) Meirelles, por outro lado, ao chamar a atenção para o fato de que não há muitas cenas de sexo no filme, enfatiza que seu tema é o "desejo" (PHILBRICK 2012: s/p) mas em outra ocasião, ele destaca a culpa como temática:

A culpa é uma espécie de freio que nos impede de ir aonde nos levariam nossas pulsões. Ela nos faz reprimir nossos impulsos e sublimar nossos desejos, criando assim a cultura.

\footnotetext{
12 “[...] bei Schnitzler geht es ja in erster Linie um Sex, Lust, Begierde. In 360 geht es dagegen vor allem um Menschlichkeit. Und um das Desaster, Mensch zu sein.”

Pandaemonium, São Paulo, v. 16, n. 22, Dez/2013, p. 138-155
} 
Pereira, V. - Sobre representação e ética em Reigen

Não há saída para nossa culpa a não ser administrá-la. Estamos condenados a não ser plenamente felizes e a viver com essa angústia instalada no peito. E ainda bem que é assim. Uma pessoa sem culpa é uma ameaça ambulante. [...] me parece que, em todas as histórias, os personagens estão lidando mesmo é com suas consciências. Não há antagonistas, a luta é sempre interna. (CESAR 2012: s/p)

Como em Reigen e La ronde, a fonte de todos os conflitos expostos em 360 é de natureza sexual, ou envolve a natureza do relacionamento amoroso, mas há uma amplitude muito maior do que a simples relação entre casais. A primeira personagem é a mulher que começa a se prostituir, procurando assim dar uma virada em sua vida. Sua história vai envolver a irmã mais nova que a acompanha nessa busca em fazer a vida fora da Eslováquia, mas que não aprova os meios da irmã mais velha. Além disso, há uma série de traições que se desenvolvem de diferentes maneiras: a tentação de trair que é reprimida, o caso amoroso extraconjugal que é encerrado, o muçulmano que evita a mulher amada por ela ser casada e, até mesmo, o homem que perde para sempre o contato com a filha que descobriu seu relacionamento fora do casamento. Mas a traição, ou sua possibilidade, não são o único foco. A narrativa também conta com um detento condenado por estupros que, pela primeira vez, volta a transitar sem acompanhamento policial e um casamento que se desfaz devido à falta de atenção do marido para com a sua mulher.

Todas as personagens vivem conflitos por causa de seus desejos, sejam eles por sexo, dinheiro, ou até mesmo álcool. Enquanto Reigen e La ronde apresentam pessoas que realizam plenamente seus desejos, mas se utilizam de palavras vazias para sustentar um falso moralismo, buscando produzir uma imagem de si mesmos que não condiz com suas ações, em 360, uma grande parte das personagens se esforça em coibir esses impulsos - e vários outros não realizam seus desejos devido à vontade do outro, que os reprime. Há uma constante problematização ética no nível do narrado, a tal ponto que a resolução dos conflitos frequentemente conta com o auxílio de elementos exteriores ao problema. Se a traição com a prostituta apenas não ocorre por causa do medo que o homem casado tem de ser descoberto, uma série de outras batalhas se desenvolve com ajuda de elementos moderadores: duas psicólogas, um imã e uma reunião dos Alcóolicos Anônimos. Esses elementos não obrigam ninguém forçosamente à solução adequada, mas são uma representação (e apresentação) de ferramentas de que a sociedade moderna dispõe para a solução de conflitos éticos: a psicoterapia, a religião e grupos de ajuda. O que o filme apresenta é a difícil batalha de cada um para vencer seus 
Pereira, V. - Sobre representação e ética em Reigen

impulsos. John, que frequenta o AA, foi visto cenas antes com uma garrafa de vinho que ele oferece cortesmente para a sua vizinha de poltrona, conseguindo se afastar assim do álcool. O imã declara que todos, inclusive ele, estão na Terra com a difícil missão de serem bons homens, e que se deve lutar por isso todos os dias. A psicóloga do detento reafirma repetidas vezes a fé que ela tem na capacidade dele de superar seus impulsos agressivos, mas ela manda reforço policial, quando o estuprador pede ajuda. Por fim, a outra psicóloga faz um discurso para seu cliente sobre o fato de que ela não pode tomar decisões por ele, é ele quem deve escolher o caminho. Esta última psicóloga é a base de sustentação ética mais fraca. Seu discurso urge para que o cliente encontre sua felicidade, acima das regras éticas impostas por religião ou sociedade: se ele está apaixonado por uma mulher casada, ele deveria esquecer a sua religião e se lançar a esse amor; apenas se não é capaz de deixar a religião em segundo plano, deveria esquecer a mulher. A decisão do argelino é pela religião. Ele busca o caminho que lhe parece certo, e não o que dá prazer.

No que diz respeito à ética do narrado, o filme trata basicamente de pessoas que buscam o caminho certo, apesar da possibilidade de fácil realização do desejo em um desvio. Mesmo o estuprador tem a opção fácil de se aproveitar de uma moça bêbada em um aeroporto interditado pela neve. É verdade que a maioria das personagens se coloca questões éticas e atua de acordo com a consciência, mesmo que isto não seja fácil, mas há também os "vilões", homens que fazem escolhas erradas, sem nenhum esboço de culpa. O desenrolar de suas histórias evidencia uma espécie de julgamento do destino, onde os "bons" têm direito a uma segunda chance e aos "maus" cabe a pena capital. Em La ronde, o julgamento divino (expressão utilizada no filme de Ophüls) sobre as ações de uma mulher adúltera só está presente no discurso hipócrita do marido, em um diálogo que reflete o mundo segundo as regras da burguesia, mas nenhuma das personagens da peça ou do filme sofre por suas ações. Já nas últimas cenas de 360 , o retorno da prostituta será marcado por sangue. Durante seu encontro com o traficante russo, a prostituta vê uma mala cheia de dinheiro e avisa seu cafetão. Apesar de o traficante ter percebido a tempo, seu capanga, cansado de ser tratado "como um cachorro" e decepcionado por ter arruinado seu casamento devido à sua completa dedicação a esse trabalho ingrato, trai a confiança de seu chefe e deixa que ele seja pego. O traficante e o cafetão, figuras incorrigíveis, se matam mutuamente, enquanto os “oprimidos" se liberam da opressão e ganham a possibilidade de um recomeço (muito 
Pereira, V. - Sobre representação e ética em Reigen

mais promissor): a prostituta foge com o dinheiro e o capanga segue sem rumo em companhia de uma simpática jovem que conheceu no mesmo dia. A jovem, irmã da prostituta, também parece se liberar de ter que ser conivente com as escolhas equivocadas da irmã. A ética do propósito retórico é demonstrar que más ações devem ser castigadas, se não pelo peso da própria consciência que deve guiar para um caminho de correção dos maus passos, então, pelo destino. Porém, de forma geral, as más ações que servem para punir aqueles que seguem o caminho errado não são castigadas pela narrativa de 360. Além dos destinos acima tratados, há a última cena do filme que apresenta o casal de marido e mulher, felizes e aparentemente bem resolvidos em seus laços matrimoniais. Eles encontram o atual parceiro de negócios do marido, que apenas conseguiu a parceria devido a uma chantagem ao descobrir que a prostituta que vagava pelo bar onde ambos se encontraram, no início do filme, teria um encontro com o mesmo. A chantagem faz com que o marido se arrependa e se reaproxime da esposa. Ao chantagista não cabe nenhum castigo divino, além de ser exposto ao casamento feliz do colega com a esposa de beleza invejável. E a apresentação do casal, agora reconciliado, sugere claramente que este é o caminho correto e bom.

Outra diferença importante é a emancipação feminina em 360. O impulso sexual não é relegado a uma categoria marginal, como é o caso da atriz em La ronde, mas é presente em praticamente todas as mulheres. Além disso, a história costuma se desenrolar de forma mais positiva para elas do que para eles. Enquanto o marido tem que lidar com um chantagista por ter considerado se envolver com uma prostituta, sua esposa termina um caso sem maiores consequências além do peso da culpa. A declaração de amor sincera do marido deixada na secretária eletrônica serve para que ela se decida a deixar o amante e dar uma segunda chance ao romance dentro do casamento. Mesmo quando Laura, que acaba de abandonar um namorado que a traía, busca ter uma noite de sexo com um completo desconhecido, isso não é representado de maneira negativa. Se, por um lado, a escolha ressalta o perigo de tal atitude (o estuprador condenado é o parceiro escolhido pela moça), por outro, sua ação não é marcada por culpa. Laura escreve um simpático bilhete ao senhor que conheceu no avião e com quem havia marcado um encontro no restaurante do aeroporto, comunicando "I met someone really cute. I've never done it before. You only live once." (MEIRELLES 2011). Apesar da preocupação que o senhor sente pelo bem-estar da moça, é importante notar que ela não se envergonha de contar a um desconhecido (e de 
Pereira, V. - Sobre representação e ética em Reigen

idade avançada) que ela se decidiu por uma noite de sexo casual, nem essa decisão é julgada por esse senhor quando ele a reencontra, e pergunta, simpático, se ela se divertiu. Não há aqui, qualquer necessidade de discursos enganosos defendendo a própria moral. $\mathrm{O}$ ato sexual por si só não é condenável, uma vez que ele não traz prejuízo a terceiros.

Parece, ainda, interessante observar que, no nível do narrar, o filme de Meirelles, apesar de adotar a estrutura episódica de Schnitzler de uma forma geral, não adota a monotonia rígida das cenas. Tanto na peça, quanto no filme de Ophüls, o esquematismo formal de cada encontro corresponde ao esquematismo biológico do ato sexual em si. A introdução desta estrutura na forma narrativa insinua que o biológico é inevitável e que o sociocultural é dominado por ele. 360, pelo contrário, opta por cenas muito mais diversificadas, longe de qualquer esquematismo formal, o que preconiza a possibilidade de alternativas de comportamento.

No que diz respeito à ética da representação fílmica, um elemento que chama a atenção é a representação de cenas de cunho sexual. Há três delas no filme: a mulher casada que encontra o amante, o estuprador que se masturba para controlar seus impulsos agressivos e a relação da prostituta com o mafioso. Embora a primeira cena demonstre uma certa cumplicidade do casal, ela é muito marcada pela culpa da mulher, por expressões de pesar mais fortes do que as de prazer, enquanto isso, as duas últimas cenas não apresentam atrativo e causam muito mais repulsa do que identificação, fazendo com que a representação sexual seja marcada por uma certa negatividade em 360 .

Alguns valores morais mudaram durante todo esse último século. O sexo passou a ser encarado de forma mais liberal, e a fidelidade é, mais do que antes, um elemento de grande valor. Em Reigen, a fidelidade e o decoro são expostos no discurso, mas parecem não ter valor suficiente para que sejam preservados também na prática. A apresentação dessa problemática na peça parece clamar por uma ação mais coerente. Cinquenta anos depois, $L a$ ronde não chega a problematizar muito essa questão. Como afirmado anteriormente, há poucos casos de clara infidelidade, o filme trata muito mais da fluidez dos relacionamentos amorosos. Não há o que ser julgado já que o amor seria algo passageiro. Por fim, 360 apresenta uma sociedade na qual, acima de tudo, deve haver o respeito pelo próximo. O próprio corpo não é o bem maior a ser guardado, a pureza não é o valor em questão. O que importa é não se aproveitar dos prazeres carnais 
Pereira, V. - Sobre representação e ética em Reigen

em detrimento do bem-estar de outro, seja ele o cônjuge que conta com a fidelidade do parceiro, o marido da mulher pela qual se está apaixonado, ou até mesmo uma mulher sem meios de se defender (no caso do estuprador). O respeito é, aqui, tão superior à questão do sexo que o divórcio de um marido fiel, mas ausente devido ao seu trabalho, é totalmente justificável. Essa evolução aponta para uma sexualidade que é mais livre no que toca o uso do próprio corpo, mas ainda é complexa e delicada no que diz respeito às relações interpessoais.

\section{Referências bibliográficas}

BoHnEnKAMP, A. (Org.) Literaturverfilmung. Stuttgart, Philipp Reclam, 2005.

CESAR, M. C. Meirelles filma histórias de culpa e desejo. In: Valor. São Paulo, 15/08/2012. http://www.casacivil.sp.gov.br/biblioteca-ccivil/noticias/MostraNoti.asp?par=1039 (20/12/2012).

Coletiva de imprensa - filme 360 (vídeo). São Paulo, 13/08/2012. http://www.youtube.com/watch?v=43crUrwBvfc (20/12/2012).

FLIEDL, K. Arthur Schnitzler: Reigen. In: Interpretationen. Dramen des 20. Jahrhunderts. Bd.1. Stuttgart, Philipp Reclam, 1996. p. 25-39.

KoEBner, T. (Org.) Erläuterung und Dokumente. Arthur Schnitzler - Reigen. Stuttgart, Philipp Reclam, 1997.

LÖSSL, U. Interview: Peter Morgan, Regisseur von “360”. In: Zitty Berlin. Berlim: 08/08/2012. http://www.zitty.de/peter-morgan-regisseur-von-360.html (20/12/2012).

MeIRELles, Fernando; MoRgan, Peter. 360. [Filme] Direção de Fernando Meirelles, Roteiro de Peter Morgan. UK, Áustria, França, Brasil: BBC Films, O2 Filmes et ali, 2011. DVD, 110 min. color. son.

OPhÜls, Max; NATANSON, Jacques. La Ronde. [Filme] Direção de Max Ophüls, roteiro adaptado de Jacques Natanson. França: Films Sacha Gordine, 1950. DVD, 97 min. preto e branco son.

PHILBRICK, J. IAR exclusive interview: director Fernando Meirelles talks '360'. In: I am Rogue. EUA, 2/08/2012. http://www.iamrogue.com/news/interviews/item/7016-iar-exclusiveinterview-director-fernando-meirelles-talks-360.html (20/12/2012).

PINARD, E. Sustento oral no processo contra Madame Bovary. In: MoReTti, F. (Org.) A cultura do romance. São Paulo, Cosac Naify, 2009. p. 210-213.

RICHTER, D. H. Keeping company in Hollywood: Ethical issues in nonfiction film. In: Narrative, Ohio, vol. 15, n. 2, 2007p. p. 140-166.

SCHNITZLER, A. Reigen. In: SCHNITZLER, A. Das dramatische Werk. Bd. 2. Frankfurt, Fischer, 1962. p. 69-132.

SCHONlaU, A. Syphilis in der Literatur. Über Ästhetik, Moral, Genie und Medizin (1880 2000). Würzburg, Königshausen \& Neumann, 2005.

SPRENGEL, P. Reigen. Zehn Dialoge. - Die ungeschriebene Regeln der Liebe. In: KIM, H.; SASSE, G. Arthur Schnitzler. Dramen und Erzählungen. Stuttgart, Philipp Reclam, 2007. p. 101-116.

Pandaemonium, São Paulo, v. 16, n. 22, Dez/2013, p. 138-155 
Pereira, V. - Sobre representação e ética em Reigen

TURNER, M. Fernando Meirelles Interview. In: View London.co.uk, Londres, 2012. http://www.viewlondon.co.uk/cinemas/fernando-meirelles-interview-feature-interview4481.html (20/12/2012).

recebido em 11/06/2013 aceito em 02/09/2013 